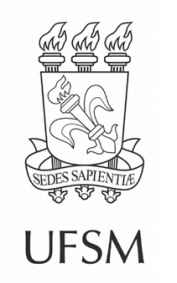

\title{
Artigos
}

\section{Genetic variability of Araucaria angustifolia Bertol. initial growth: subsidy to the formation of seed orchards}

\author{
Variabilidade genética do crescimento inicial de Araucaria angustifolia \\ Bertol.: subsídio para formação de pomares de sementes
}

\section{Dionatan Gerber ${ }^{\odot}$, Eleandro José Brun " $\odot$, Larissa Regina Topanotti $11 \odot$, Josângela de Jesus Ferreira IV $\oplus$, Douglas Anry Porrua ${ }^{\circ}$, Mauricio Romero Gorenstein " $₫$, Américo Wagner Júnior"}

\author{
I Instituto Politécnico de Bragança, Bragança, Portugal \\ " Universidade Tecnológica Federal do Paraná, Dois Vizinhos, PR, Brazil \\ III Universidade Federal de Santa Catarina, Curitibanos, PR, Brazil \\ iv Pesquisadora Autônoma, Bom Jesus dos Perdões, SP, Brazil
}

\begin{abstract}
The species Araucaria angustifolia Bertol. is native from Brazil, and it is now an endangered species due to the anthropic actions for several years. The objective of this study was to evaluate the genetic variability of Araucaria angustifolia based on initial growth qualitative and quantitative variables in a provenance and progeny test. Based on this performance, the genotypes with higher presence of superior characteristics were selected, to subsidize the formation of seed orchards. The matrices from Guarapuava-PR and Palmeira-SC were chosen according to their biometric and morphometric characteristics. Each matrix received a control code card. The matrices trees were assessed according to dendrometric and sanitary characteristics, and the harvested pine cones were evaluated for their weight, volume, and sanity. A total of 14 matrices from Palmeira-SC and 10 matrices from GuarapuavaPR were selected. The pinecones from each selected matrix were evaluated by quantitative characters. The seeds of these pineconeswere separated according to matrix tree, and they were used in the experiment to evaluatethe emergency and initial growth among genotypes.All the statistical analyses were conducted in a computational application about genetics -GENES ${ }^{\circledR}$ and on the software R Studio. It was verified that there is genetic variability among the provenances and progenies for most of the quantitative characters studied for $A$. angustifolia, and thus, there is also the possibility of obtaining gains through selection among and within the provenances. The selection among and within the provenances suggests that it is possible to reach significant genetic gains, especially for weight and diameter of pine cones, weight, and number of seeds per pinecone, and tree growth.
\end{abstract}

Keywords: Pine cone; Pine seeds; Genetic conservation 


\section{RESUMO}

A Araucaria angustifolia Bertol. é uma espécie nativa do Brasil que, devido a ação antrópica ao longo de vários anos, a colocou sob ameaça de extinção. O objetivo do trabalho foi avaliar a variabilidade genética de Araucaria angustifolia com base em variáveis qualitativas e quantitativas de crescimento inicial em teste de procedências e progênies, selecionando-se aquelas com maior presença de superioridade como subsídio para a formação de pomares de sementes. Um teste de procedência e progênies foi instalado em casa de vegetação, utilizando-se as árvores matrizes de Guarapuava-PR e Palmeira-SC, de acordo com suas características biométricas e morfométricas. Cada matriz recebeu código de controle. As árvores matrizes foram avaliadas de acordo com as características dendrométricas e sanitárias, bem como as pinhas colhidas, quanto ao peso, volume e sanidade. Foram selecionadas 14 matrizes de Palmeira-SC e 10 matrizes de Guarapuava-PR. As pinhas de cada matriz selecionada foram avaliadas utilizando variáveis quantitativas. As sementes dessas pinhas, de acordo com a árvore matricial, foram separadas e utilizadas no experimento para avaliar a emergência das sementes e o crescimento inicial entre os genótipos. Todas as análises estatísticas foram realizadas pelos softwares GENES® e R Studio. Verificou-se que existe variabilidade genética entre as procedências e progênies para a maioria dos caracteres quantitativos estudados para a espécie e, portanto, a possibilidade de obter ganhos através da seleção entre e dentro das procedências. A seleção entre e dentro das procedências sugere a possibilidade de alcançar ganhos genéticos significativos, especialmente para caracteres de peso e diâmetro de pinhas, peso e número de sementes por pinha e crescimento das árvores.

Palavras-chave: Pinha; Sementes de pinhão; Conservação genética

\section{INTRODUCTION}

The species Araucaria angustifolia (Bertol.) Kuntze is native from Brazil, with predominant occurrence in the South region and in a small population in the Southeast Region (CARVALHO; NAKAGAWA, 2012). Naturally, this specie occurs in altitudes between 500 and 1.500 m (MATTOS, 2011), in Cfa (subtropical with hot summer) or Cfb (subtropical with temperate summer) climates, according to Köppen classification, which are characterized as humid subtropical climates without dry season and with humid and rainy summer (ALVARES; SENTELHAS; STAPE, 2018). The species plays an important socio-economic role through its wood use, which enables countless possibilities, and the consumption of its edible fruit (ZANETTE, 2014).

However, Araucaria angustifolia is found in reduced areas, not only in its primary forestry formation but also in secondary forests. Most of the genotypes come from natural regeneration observed after intense extractive exploitation, that it has been 
practiced for many years. Estimates indicate the existence of one to two percent of the original areas covered by the Ombrophilous Mixed Forest, centered on the Parana, Santa Catarina and Rio Grande do Sul States of Brazil (WREGE et al., 2016).

Currently, the species is under threat of extinction in Brazil, with less than $2 \%$ of its original area (SOUZA; AGUIAR, 2012). This scenario could be reversed by carrying out new scientific researches on genetic improvement and silviculture, efficiently, seeking to find individuals in its natural environment and to develop more productive genotypes for planting, mainly focusing on the production of the pine cone and protection of native remnants.

The Araucaria angustifolia is the forest species that may have suffered the greatest loss of superior genetic material, since the most vigorous trees were suppressed to obtain wood, generating the negative selection process. Despite the degradation that occurred in our country, Brazil still possesses a huge diversity of tree species, and only a few of them have an effective genetic improvement program aiming to produce productive materials to stimulate commercial-scale planting, such as Araucaria angustifolia.

Therefore, it is extremely important that such studies on the species, besides playing a key role in the ecosystem conservation, bring good profits to the producers. As superior materials still exist in nature and to conserve such genetic characteristics, it is essential to prospect the genotypes in loco in the occurrence areas, to analyze and characterize the properties of the seedlings formed and the fruits to be produced to subsequent selection.

The objective of the work was to evaluate the genetic variability of Araucaria angustifolia based on qualitative and quantitative variables of initial growth in a provenance and progenies test. Based on this performance, genotypes with a higher presence of superior characteristics were selected to subsidize the formation of seed orchards. 


\section{MATERIALS AND METHODS}

The araucaria seeds were collected from two regions of Southern Brazil, located in the Araucarias Natural Municipal Park, Guarapuava-PR (coordinates $25^{\circ} 20^{\prime} 11^{\prime \prime}-25^{\circ} 20^{\prime} 58^{\prime \prime} \mathrm{S}$ and $51^{\circ} 27^{\prime} 19^{\prime \prime}-51^{\circ} 28^{\prime} 28^{\prime \prime} \mathrm{W}$, in a region with the occurrence of Ombrophylous Mixed Forest) and in a rural property at Palmeira-SC city (coordinates $27^{\circ} 29^{\prime} 04^{\prime \prime}-27^{\circ} 29^{\prime} 18^{\prime \prime} \mathrm{S}$ and $50^{\circ} 08^{\prime} 51^{\prime \prime}-50^{\circ} 09^{\prime} 01^{\prime \prime} \mathrm{W}$, at $870 \mathrm{~m}$ of average altitude, in the South Plateau of Santa Catarina, in a region of Ombrophylous Mixed Forest).

The matrices were chosen according to their biometric and morphometric characteristics [total height (h), crown projection area (ca), diameter at breast height (dbh), number of pine cones per matrix, absence of bifurcation and absence of pests and diseases, respecting a minimum distance of $100 \mathrm{~m}$ among trees]. Each matrix received a control code card. The matrices trees were assessed according to dendrometric and sanitary characteristics, as well as the harvested pine cones, which were evaluated for their weight, volume, and sanity. A total of 14 matrices trees from Palmeira-SC and 10 from Guarapuava-PR were selected.

The total height of the matrices was collected using a Vertex IV hypsometer. The measurement of dbh was performed using a measuring tape, projecting the height of $1.30 \mathrm{~m}$ from ground level. The crown projection area was obtained using a $50 \mathrm{~m}$ tape measure, extending it through the crown, adopting the center of the plant as the reference point, making two measures of diameter.

Regarding the dendrometric characteristics, the matrices from Guarapuava showed a mean height of $24.15 \pm 2.15 \mathrm{~m}$, mean dbh of $85.68 \pm 8.86 \mathrm{~cm}$, and a mean crown projection area of $215.8 \pm 30.82 \mathrm{~m}^{2}$. The means for the matrices from Palmeira were $18.0 \pm 1.2 \mathrm{~m}, 53.96 \pm 18.31 \mathrm{~cm}$ and $105.68 \pm 57.92 \mathrm{~m}^{2}$ for height, dbh, and crown projection area, respectively.

It was harvested five pine cones by matrix tree (24 matrices), randomly, totalizing 120 cones. The harvest was performed from March to June 2015. The pine cones were 
evaluated by quantitative characters, such as circumference, height, and total weight. Besides, the number of viable seeds, total weight of seeds, weight of "failure" seeds and pine cone central axis were measured for each pine cone. The data were analyzed using descriptive statistics and Pearson's correlation. The seeds of these pine cones were separated and they were used in the experiment to evaluated de emergency and initial growth among genotypes.

The experiment with seeds was carried out in the Unidade de Ensino e Pesquisa Viveiro de Produção de Mudas Hortícolas, da Universidade Tecnológica Federal do Paraná - Câmpus Dois Vizinhos. In the greenhouse, the seeds from each matrix tree selected were sowed in a commercial substrate, using trays with 96 cells, each with 180 $\mathrm{cm}^{3}$ of tube space. Each tube received a seed, totalizing 150 tubes for each treatment. The sowing occurred directly in the tubes, placing the seed in an inclined way on the substrate (WENDLING; DELGADO, 2008), that is, with the thinner part down. The irrigation inside the greenhouse was sprayed with eight 30-minute irrigation shifts spaced every three hours. The temperature was controlled at $25^{\circ} \mathrm{C}$ and relative air humidity was kept close to $90 \%$.

The Emergency Percentage (E) was performed in a greenhouse with controlled temperature and irrigation. A total of 3 repetitions of 50 seeds per matrix was used. The Index Speed Emergency (ISE) of the progenies was conducted in a similar way to the seedling emergence percentage test, which was used to carry out their evaluation. However, the observations were performed daily, until the number of seedlings became constant since the emergence of the first seedling (OLIVEIRA et al., 2009). The Mean Time of Emergency (MTE) was calculated through daily annotations of the number of emerged progenies, until the number of emergence became constant (MAGUIRE, 1962).

After 30 days of the first emergence of each treatment, it was conducted the first measurement of total height and collar diameter. The total height of each individual was collected using a ruler graduated in intervals of $0.1 \mathrm{~cm}$. The equipment was positioned vertically as close to the plant as possible, leaving its base at the same level as the ground. The distance between the base of the plant on the ground and 
the end of the stem (yolk) was considered as total height. The collar diameter (cd) was obtained through the use of a digital caliper, placing it in the bottom of the plant, close to the soil surface. The direction of the largest length of the tray was standardized as a reference to position the caliper.

The first survival assessments were performed at 90 days after the first emergence. The survival was based on the counting of live plants in the planted area, and the percentage of live plants corresponded to the survival of the individuals.

All the data collected, both in the selection of matrices and production of seedlings in the nursery, compared to their provenances (Palmeira-SC and Guarapuava-PR) were submitted to analysis of variance and Scott-Knott's tests. Before this, the data were submitted to the normality test of Lilliefors.

The genetic variability was evaluated by the nearest neighbor clustering method, using Mahalanobis distance as a measure of dissimilarity and by the Tocher method based on standardized mean Euclidean distance. All the statistical analyzes were performed in the genetic software application - GENES ${ }^{\circledR}(C R U Z, 2006)$ and R Studio software (R STUDIO TEAM, 2015).

To identify the superior materials, the frequency of superiority of the set of variables analyzed was used (PALADINI, 2016), seeking the progenies that maintained the behavior of higher frequency in the analyzed attributes. To calculate the superiority frequency, the progenies were ranked from $1^{\text {st }}$ to $24^{\text {th }}$ placement in each variable, classifying them by means of the variables in descending order, for desirable characteristics. From each ranking, the sum was made among the variables and the twenty percent with better placement were pre-selected.

The provenance and progeny test was installed in an area of $1.3 \mathrm{ha}$, located at UTFPR - Câmpus Dois Vizinhos, at Dois Vizinhos city, Southwest region of Paraná State, Brazil. The region is located geomorphologically in the third plateau of Paraná or plateau of Guarapuava in the Southwest region of the State of Paraná, with an average altitude of $510 \mathrm{~m}$, latitude of $25^{\circ} 44^{\prime} \mathrm{S}$ and longitude of $53^{\circ} 04^{\prime} \mathrm{W}$. The area was divided into randomized blocks with 24 progenies. Three replications were used, with 72 linear plots of 5 plants, totaling 360 progenies planted in an experimental area. 


\section{RESULTS AND DISCUSSION}

\subsection{Characteristics and average production of seeds per matrix}

The biometric characteristics of pine cone length, mean pine cone weight, average number of pine seeds (or pine nuts), average weight of intact pine seeds, and number of pine seeds not formed by pine cone showed that there were differences regarding the descriptive evaluation among provenances and progenies studied.

Figure 1 presents boxplot graphics for the number of intact seeds and the number of empty seeds. The results were represented by the median and first and third quartiles of the data evaluated, where the asterisks represent the data' discrepant values. Thus, both the number of intact seeds and empty seeds as well as the failures varied among provenances.

For the Guarapuava-PR provenance, the pine cones had an average of $1.62 \mathrm{~kg}$, with the lightest presenting $0.43 \mathrm{~kg}$ and the heaviest $2.20 \mathrm{~kg}$ (Figure 1A). The provenance of Palmeira-SC had an average of $1.91 \mathrm{~kg}$, which the lightest value showed $0.94 \mathrm{~kg}$ and the heaviest $3.38 \mathrm{~kg}$. Figueiredo Filho et al. (2011), analyzing the forest remnants of the Southern Center of the State of Paraná, determined values of 1.85 and $1.91 \mathrm{~kg}$ for pine cones from naturally occurring trees and homogenous plantations, respectively. Silva (2006) obtained in Caçador-SC average yields of 1.48 and $0.73 \mathrm{~kg}$, for the pine cones from naturally occurring matrices and forest plantations, respectively. Vernalha et al. (1972), in a population in Curitiba-PR, evaluated 414 pinecones and they determined the average weight of the strobiles of $1.77 \mathrm{~kg}$.Thus, it can be verified that the results obtained in the present work are in agreement with values found by Vernalha et al. (1972), Silva (2006) and Figueiredo Filho et al. (2011), that is, the matrices presented the same pattern already evaluated for species.

The mean diameter of the pine cones in the Guarapuava-PR provenance was $15.74 \mathrm{~cm}$, varying from 13.37 to $17.19 \mathrm{~cm}$, while Palmeira-SC was $16.75 \mathrm{~cm}$, with a variation of 13.09 to $21.49 \mathrm{~cm}$ (Figure 1B). Silva (2006) found an average of $12.4 \mathrm{~cm}$ in diameter of the pine cones from naturally occurring plants. Figueiredo Filho et al. (2011) found an average of $15.1 \mathrm{~cm}$., in a study involving the production of $A$. angustifolia seeds 
in a natural forest in the Center-South of the State of Paraná. According to Carvalho and Nakagawa (2002), the pine cones of $A$. angustifolia have a diameter ranging from 10 to $25 \mathrm{~cm}$, reaching up to $4.7 \mathrm{~kg}$ of mass of fresh matter. Pires (2016) evaluated the biometric characterization of pine cones and seeds of $A$. angustifolia in the municipality of Palma Sola - SC, and obtained an average of $13.99 \mathrm{~cm}$ in diameter.

Figure 1 - Boxplot with mean values of strobiles (A), the average diameter of pine cone (B), the average weight of viable seeds (C), the average weight of unformed pine seeds (D), mean weight per seed (E) and average number of viable seeds per pinecone (F) from two sources (Guarapuava-PR and Palmeira-SC) of Araucaria angustifolia. (-) Median; $(*)$ maximum and minimum observed values

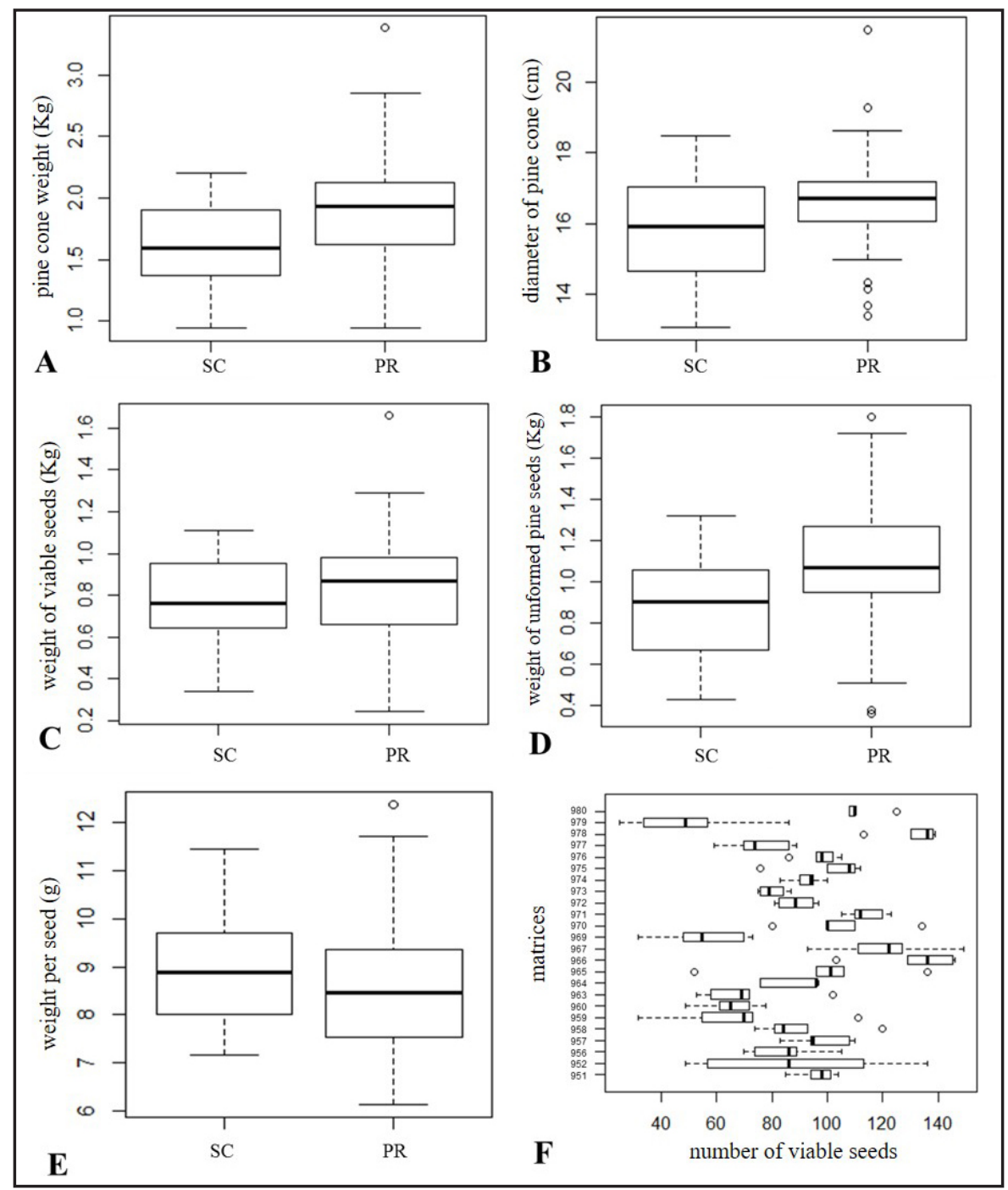

Source: Authors (2020) 
Krupek and Ribeiro (2010) assessed matrices of A. angustifolia from forest remnants of the municipality of Turvo in the State of Paraná. They found low variation in the biometric characteristics of the pine cones, with diameter oscillating between 12.6 and $14.6 \mathrm{~cm}$ and mass of fresh matter varying from 0.870 to $1.450 \mathrm{~kg}$. The values found in the present study had a greater variation when compared to those found by Krupek and Ribeiro (2010) and Pires (2016), and it is among the range cited by Carvalho and Nakagawa (2012). Such behavior may be associated with the analysis cycle, as well as to the genetic behavior of the material or by the influence of production obtained in the last cycle.

The average production of pine seeds per pine cone was 0.755 and $0.821 \mathrm{~kg}$ for Guarapuava-PR and Palmeira-SC, respectively (Figure 1C). The mean weight per seed in the Guarapuava-PR provenance was $8.90 \mathrm{~g}$, ranging from 10.55 to $7.91 \mathrm{~g}$, while Palmeira-SC was $8.53 \mathrm{~g}$, with a variation of 11.05 to $6.62 \mathrm{~g}$ (Figure 1E). The size of the pine nuts from Palmeira-SC, although smaller than those from Guarapuava-PR, was above the margin obtained by Anselmini, Zanette and Bona (2006), whose work showed a mass of the pine nuts of $7.72 \mathrm{~g}$, with a maximum of $12.65 \mathrm{~g}$ and a minimum of 2.8 g. Solórzano-Filho (2001) evaluated A. angustifolia population in Campos do JordãoSP and obtained an average dry matter mass of pine nuts of $5.5 \mathrm{~g}$, with a maximum of 8.1 and a minimum of $3.0 \mathrm{~g}$.

Figures $1 \mathrm{C}$ and $1 \mathrm{D}$ indicated that the provenance of Palmeira-SC produced a larger number of pine nuts per pine cone compared to the provenance of GuarapuavaPR. One hypothesis for this is that the trees from Palmeira-SC are located in an environment of grasslands and, therefore, free from the crowns' competition by sunlight, unlike the Araucaria Park in Guarapuava-PR, characterized as a forest with greater density of trees and closed forest canopy, thus occurring canopy competition throughout the tree life cycle.

Regarding the seeds per strobile, an average of 96.6 was found for PalmeiraSC and 84.8 for Guarapuava-PR. The PASC-966 and PASC-978 matrices trees showed 
differences in the descriptive analysis, presenting higher average numbers of pine nuts per pine cone, with values of 131.8 and 131.2, respectively (Figure 1F). Figueiredo Filho et al. (2011) found 78.9 seeds per strobile in an advanced forest in the municipality of Irati-PR. Mantovani, Morellato and Reis (2004) found, in a natural forest in the State of São Paulo, 93.9 seeds per strobile. Anselmini, Zanette and Bona (2006), working with progenies of A. angustifolia located in the Sector of Agricultural Sciences in Curitiba-PR, found the highest average of 60 pine nuts per primary branch pine and 40 pine nuts per secondary branch pine. Solórzano-Filho (2001), working with a natural population, found the average number of 56 to 141 pine nuts per pine cone.

According to Silva (2006), the high density of trees in a specific local can generate a strong intraspecific competition process, with negative relation between density and development of the plants, which consequently causes each plant to increase its production. Differences in the number of seeds per pine cone may be related to unfavorable climatic conditions during flowering, which leads to deficiency in the pollination process. Although the species is pollinated by the wind, both pollen and forest characteristics of the species make it difficult to move (PIRES, 2016).

Also, water deficiencies may lead to reduced assimilation by plants and abortion or reduction of seed development, due to the carbohydrate supply limitation because of the reduction of the photosynthetic rate. Drying periods during flowering have the effect of reducing the seeds number, but the size of seeds, in this case, is less affected. The temperature also influences seed production, since high temperatures, during the period of transference of photoassimilates to the seeds, can cause damage to seed quality, due to the decrease in the photosynthetic rate (MARCOS FILHO, 2005).

Since $A$. angustifolia is a dioecious species, the presence of nearby male trees is a factor that also influences seed production (KRUPEK; RIBEIRO, 2010), whose unequal proportion of sexes causes an unbalanced contribution in the number of gametes favoring the most present sex in the area (SOUZA; HATTEMER, 2003). Another possible cause is the difference in seed production among araucaria genotypes is their cyclic production, that is, the period of high production followed by low production (MATTOS, 
2011), which may also influence the production of seeds among the matrices trees. Since there are no previous studies, it was not possible to deduce in what period of production each individual is in the populations studied.

Krupek and Ribeiro (2010) and, Mantovani, Morellato and Reis (2004) found greater variations in the biometric characteristics of $A$. angustifolia seeds, especially among different plants, since within each strobile the variation of length, width, thickness, and mass was low. Anselmini (2005) also found a smaller variation of the biometric characteristics of the seeds inside pine cones. The greatest variation within the species occurs within plants, which indicates environmental effects during development rather than genetic differences among matrices trees. However, as in the present study the matrices of each progeny were in the same forest remnant and are exposed under the same soil and climatic conditions, the differences found may indicate genetic differences among the matrices and progenies.

\subsection{Evaluation of physical characteristics of the emergence and development of progenies}

The germination of $A$. angustifolia seeds under controlled conditions occurs in 35 days, while sowing in the soil occurs between 60 and 120 days (CARVALHO; NAKAGAWA, 2012). In the present work, the progenies of the two provenances began to emerge between the thirtieth and the seventieth day after the beginning of the experiment, and the test was completed after 90 days of sowing in a greenhouse, with a controlled temperature of $25^{\circ} \mathrm{C}$ and relative humidity of $90 \%$.

In the case of emergency (E), Index Speed Emergency (ISE), and meantime of emergence (MTE), there was a significant influence of the progenies and provenances tested in these variables (Table 1). The progenies GUPR-951, GUPR-956, GUPR-957, GUPR-960, GUPR-963, GUPR-964, GUPR-965, PASC-969, PASC-971, PASC- 974, PASC975 and PASC-977 were grouped in the highest emergency percentages group, differing from the other progenies and provenances, with values lower than $66.67 \%$ of emergency, falling into the second group. The formation of two groups allowed verifying that the seeds presented a satisfactory pattern regarding the emergence, with little variation among them. 
To evaluate the physical characteristics of the seeds, the seed emergence of A. angustifolia was uneven and slow, which may lead to losses due to the attack of pathogens as well as to the uneven seedling' development. Pires (2016) evaluated the emergence of seedlings among araucaria matrices from the population of Palma Sola city, State of Santa Catarina and he obtained an emergency of 56.25\%, considered by the author as high.

Table 1 - Percentage of Emergency (E), Index Speed Emergency (ISE) and Mean Time of Emergency (MTE) of different progenies of A. angustifolia, according to their provenance

\begin{tabular}{|c|c|c|c|}
\hline Progenie & $E(\%)$ & ISE & MTE (days)* \\
\hline GUPR-951** & $78.00 a^{* \star \star}$ & $0.88 \mathrm{~b}$ & $45.77 \mathrm{c}$ \\
\hline GUPR-952 & $51.33 \mathrm{~b}$ & $0.69 \mathrm{~b}$ & 39.31 a \\
\hline GUPR-956 & $72.00 \mathrm{a}$ & $0.86 \mathrm{~b}$ & $43.56 \mathrm{c}$ \\
\hline GUPR-957 & $78.67 \mathrm{a}$ & $0.87 \mathrm{~b}$ & $46.93 \mathrm{c}$ \\
\hline GUPR-958 & $66.67 \mathrm{~b}$ & $0.67 \mathrm{~b}$ & $51.61 \mathrm{~d}$ \\
\hline GUPR-959 & $72.00 \mathrm{a}$ & $0,86 \mathrm{~b}$ & $43.20 \mathrm{c}$ \\
\hline GUPR-960 & $76.67 \mathrm{a}$ & $0.91 \mathrm{~b}$ & $44.46 \mathrm{c}$ \\
\hline GUPR-963 & $86.00 \mathrm{a}$ & $0.98 \mathrm{~b}$ & $44.82 \mathrm{c}$ \\
\hline GUPR-964 & $78.00 \mathrm{a}$ & $0.90 \mathrm{~b}$ & $44.69 c$ \\
\hline GUPR-965 & $77.33 \mathrm{a}$ & $0.92 b$ & $43.56 \mathrm{c}$ \\
\hline PASC-966 & $57.33 \mathrm{~b}$ & $0.59 \mathrm{~b}$ & $50.06 d$ \\
\hline PASC-967 & $54.00 \mathrm{~b}$ & $0.46 \mathrm{~b}$ & $60.02 \mathrm{f}$ \\
\hline PASC-969 & $92.00 \mathrm{a}$ & $1.25 \mathrm{a}$ & $37.48 a$ \\
\hline PASC-970 & $63.33 \mathrm{~b}$ & $0.57 \mathrm{~b}$ & 56.18 e \\
\hline PASC-971 & $94.00 \mathrm{a}$ & $1.25 \mathrm{a}$ & $39.10 \mathrm{a}$ \\
\hline PASC-972 & $40.00 \mathrm{~b}$ & $0.48 \mathrm{~b}$ & $42.47 c$ \\
\hline PASC-973 & $85.33 \mathrm{a}$ & $1.13 a$ & 38.63 a \\
\hline PASC-974 & $83.33 \mathrm{a}$ & $0.81 \mathrm{~b}$ & 53.67 e \\
\hline PASC-975 & 80.67 a & $0.90 \mathrm{~b}$ & $45.95 \mathrm{c}$ \\
\hline PASC-976 & $62.00 \mathrm{~b}$ & $0.54 \mathrm{~b}$ & $59.39 \mathrm{f}$ \\
\hline PASC-977 & $70.00 \mathrm{a}$ & $0.86 \mathrm{~b}$ & $41.61 \mathrm{~b}$ \\
\hline PASC-978 & $48.67 \mathrm{~b}$ & $0.39 \mathrm{~b}$ & $63.59 \mathrm{~g}$ \\
\hline PASC-979 & $52.67 \mathrm{~b}$ & $0.55 \mathrm{~b}$ & $49.51 \mathrm{~d}$ \\
\hline PASC-980 & $64.00 \mathrm{~b}$ & $0.60 \mathrm{~b}$ & $55.13 \mathrm{e}$ \\
\hline CV(\%) & 14.92 & 15.20 & 1.78 \\
\hline
\end{tabular}

Source: Authors (2020)

Where: ***Significant to $5 \%$ probability of error by the Scott-Knott test; * Data transformed into the root of $x+1 . * *$ GRUPR- Guarapuava and PASC - Palmeiras. 
Krupek and Ribeiro (2010) evaluated 120 seeds of $A$. angustifolia sown in tubes with different substrate types and found an emergency of $60.9 \%$, considered by the authors also as high. Anselmini (2005) sowed araucaria seeds in commercial substrate and he observed germination between $45.7 \%$ and $67.9 \%$, for seeds obtained from secondary and primary branches, respectively. Considering the average emergency of $67.67 \%$ and $73.67 \%$ according to the provenance (Palmeira-SC and Guarapuava-PR, respectively), these were high compared to the studies cited above.

The lowest Mean Time of Emergency (MTE) was desirable with GUPR-952, PASC969, PASC-971, and PASC-973 progenies ranging from 37 to 39 days (Table 1). For MTE, the progenies were grouped in seven groups, which presented greater variation in comparison to the emergency. This emphasizes what was described by MoreiraSouza and Cardoso (2003), that MTE has a slow and uneven behavior. Regarding the emergence speed index, two groups were formed, the one composed by the progenies PASC-969, PASC-971 and PASC-973 with the highest mean, that is, exhibiting the highest emergence speed of the seedlings, differing from the other progenies studied, grouped in the second group formed (Table 1). The low EVI of the PASC-967 and PASC972 progenies, together with the low emergence percentage, may indicate that they had fewer reserves in the seeds or perhaps a lower moisture content in the harvested time compared to the others, requiring a longer time for the germination processes activation.

According to Guedes et al. (2015), the higher germination speed reflects indirectly in higher rates of initial vigor of seedlings, since the faster growth of the aerial part and the root system allows greater use of the water and nutritional reserves of the soil, besides allowing a better development of the physiological processes. When the most vigorous seedlings emerge rapidly from the soil, they initiate the photosynthetic process, thus maintaining higher growth rates throughout the development period (SCHUSC et al., 1999). The progenies PASC-963, PASC-969, PASC-971, PASC-973, and PASC-975 showed higher seedling growth and superiority in the rate of emergence, 
highlighting them in comparison to the other matrices.

All the variables described for the biometry of the seedlings also had a significant effect of the progenies (Table 2), except for total height (h) in the 30 and 60 days after sowing, since they did not differ statistically among themselves. However, in the 90 days, there was a significant difference between progenies and provenances, it being the progenies GUPR-952, GUPR-958, GUPR-960, GUPR-963, GUPR-964, GUPR-965, PASC-967, PASC-970, PASC-971, PASC-979, PASC-972, PASC-974, PASC-975, PASC-977, PASC-979 and PASC-980 those with the highest average values for the total height of the seedlings, in which they ranged from 29.9 to $24.7 \mathrm{~cm}$.

For collar diameter (cd), all progenies differed among themselves in the 30,60, and 90 days after sowing by grouping the progenies PASC-966, PASC-974, and PASC979 as those with the highest mean values for the diameter, which varied between 5.97 and $6.26 \mathrm{~mm}$ (Table 2).

According to Carvalho and Nakagawa (2012), the more reserves present in the seeds, the greater the development of the embryonic axis. In addition, the presence of a larger reserve in the seed will influence the establishment of the seedling, allowing greater vigor and / or that it survives for a longer period under unfavorable conditions (SANTOS et al., 2009).

The collar diameter is an important characteristic in the evaluation of the seedlings' survival and growth in the field, because as the diameter increases, it provides greater capacity for formation and growth of new roots (SOUZA, 2006). The PASC-974 progeny was grouped in that group of higher average increase in height and diameter of the collar, standing out in these variables in relation to the other progenies.

The Tocher grouping method based on standardized Euclidean mean distance allowed the formation of nine distinct groups of progenies (Table 3), confirming the presence of variability in the germplasm studied, detected by analysis of variance (Table 1 and 2). The group I had the highest number of progenies (GUPR-952, GUPR- 
958, GUPR-960, GUPR-964, GUPR-965, PASC-971, PASC-972 and PASC-977) from the 24 analyzed progenies, constituted by five from Guarapuava-PR and three from Palmeira.

Table 2 - Growth in height (h) and collar diameter (cd) in the 30, 60 and 90 days after seeds planting and mean increase in height (Inc. in h) and collar diameter (Inc. in cd) after 90 days of different progenies of Araucaria angustifolia, according to their provenance

\begin{tabular}{|c|c|c|c|c|c|c|c|c|}
\hline \multirow[t]{2}{*}{ Progenie } & $\begin{array}{c}\text { h } \\
(\mathrm{cm})\end{array}$ & $\begin{array}{c}c d \\
(\mathrm{~mm})\end{array}$ & $\begin{array}{c}\mathrm{h} \\
(\mathrm{cm})\end{array}$ & $\begin{array}{c}\mathrm{cd} \\
(\mathrm{mm})\end{array}$ & $\begin{array}{c}\mathrm{h} \\
(\mathrm{cm})\end{array}$ & $\begin{array}{c}\mathrm{cd} \\
(\mathrm{mm})\end{array}$ & $\begin{array}{l}\text { Inc. in } \\
\mathrm{h}(\mathrm{cm})\end{array}$ & $\begin{array}{l}\text { Inc. in } \\
\text { cd (cm) }\end{array}$ \\
\hline & \multicolumn{2}{|c|}{30 days } & \multicolumn{2}{|c|}{60 days } & \multicolumn{2}{|c|}{90 days } & \multicolumn{2}{|c|}{90 days } \\
\hline GUPR-951 & $\begin{array}{c}9.8 \\
\mathrm{~ns}^{* *}\end{array}$ & $1.20 d^{*}$ & $\begin{array}{l}19.2 \\
\mathrm{~ns}^{\star \star}\end{array}$ & $3.37 \mathrm{~b}$ & $23.4 \mathrm{~b}$ & $4.32 \mathrm{c}$ & $13.6 \mathrm{~b}$ & $3.12 a^{*}$ \\
\hline GUPR-952 & 7.0 & $2.30 \mathrm{c}$ & 17.8 & $2.80 \mathrm{~b}$ & $25.4 \mathrm{a}$ & $3.40 d$ & $18.4 \mathrm{a}$ & $1.10 \mathrm{~d}$ \\
\hline GUPR-956 & 9.0 & $3.60 \mathrm{~b}$ & 17.8 & $2.54 \mathrm{~b}$ & $19.4 \mathrm{~b}$ & $4.78 \mathrm{~b}$ & $10.4 \mathrm{~b}$ & $1.18 d$ \\
\hline GUPR-957 & 7.2 & $1.24 \mathrm{~d}$ & 15.7 & $3.19 b$ & $23.2 b$ & $3.84 \mathrm{~d}$ & $16.0 \mathrm{~b}$ & $2.60 \mathrm{a}$ \\
\hline GUPR-958 & 6.2 & $2.28 \mathrm{c}$ & 17.6 & $3.02 b$ & $26.4 \mathrm{a}$ & $3.80 \mathrm{~d}$ & $20.4 a$ & $1.52 \mathrm{~d}$ \\
\hline GUPR-959 & 7.2 & $2.35 \mathrm{~b}$ & 15.7 & $2.73 b$ & $18.4 \mathrm{~b}$ & $3.42 \mathrm{~d}$ & $11.2 \mathrm{~b}$ & $1.07 \mathrm{~d}$ \\
\hline GUPR-960 & 4.8 & $1.56 \mathrm{c}$ & 18.4 & $3.30 \mathrm{~b}$ & $25.8 \mathrm{a}$ & $4.34 \mathrm{c}$ & $21.0 \mathrm{a}$ & $2.78 \mathrm{~b}$ \\
\hline GUPR-963 & $1 ., 3$ & $1.78 \mathrm{c}$ & 19.3 & $3.43 b$ & $25.0 \mathrm{a}$ & $4.04 \mathrm{C}$ & $14.7 \mathrm{~b}$ & $2.26 \mathrm{c}$ \\
\hline GUPR-964 & 8,1 & $1.78 \mathrm{c}$ & 18.4 & $2.48 \mathrm{~b}$ & $26.9 a$ & $3.20 \mathrm{~d}$ & $18.8 \mathrm{a}$ & $1.42 \mathrm{~d}$ \\
\hline GUPR-965 & 8.0 & $1.42 \mathrm{c}$ & 20.0 & $2.64 \mathrm{~b}$ & $27.4 \mathrm{a}$ & $4.46 \mathrm{c}$ & $19.4 \mathrm{a}$ & $3.04 \mathrm{~b}$ \\
\hline PASC-966 & 8.6 & $4.03 \mathrm{a}$ & 19.3 & $4.73 a$ & $23.8 \mathrm{~b}$ & $5.97 a$ & $15.2 \mathrm{~b}$ & $1.94 \mathrm{c}$ \\
\hline PASC-967 & 5.3 & $3.11 \mathrm{~b}$ & 19.2 & $3.86 \mathrm{a}$ & $24.7 \mathrm{a}$ & $5.43 \mathrm{~b}$ & $19.4 \mathrm{a}$ & $2.32 \mathrm{c}$ \\
\hline PASC-969 & 7.5 & $2.18 \mathrm{c}$ & 18.5 & $3.46 \mathrm{~b}$ & $22.0 \mathrm{~b}$ & $4.81 \mathrm{~b}$ & $14.5 \mathrm{~b}$ & $2.63 \mathrm{~b}$ \\
\hline PASC-970 & 7.3 & $3.83 a$ & 19.7 & $4.30 \mathrm{a}$ & $28.1 \mathrm{a}$ & $4.95 \mathrm{~b}$ & $20.8 \mathrm{a}$ & $1.12 \mathrm{~d}$ \\
\hline PASC-971 & 7.0 & $2.00 \mathrm{c}$ & 18.3 & $2.97 \mathrm{~b}$ & $27.9 \mathrm{a}$ & $4.41 \mathrm{c}$ & $20.9 a$ & $2.41 \mathrm{c}$ \\
\hline PASC-972 & 5.1 & $2.16 \mathrm{c}$ & 19.0 & $2.96 \mathrm{~b}$ & $29.0 \mathrm{a}$ & $4.52 \mathrm{c}$ & $23.9 \mathrm{a}$ & $2.36 \mathrm{c}$ \\
\hline PASC-973 & 6.1 & $1.24 \mathrm{c}$ & 14.2 & $3.25 b$ & $22.0 \mathrm{~b}$ & $4.63 c$ & $15.9 \mathrm{~b}$ & $3.39 \mathrm{~b}$ \\
\hline PASC-974 & 8.3 & $1.44 \mathrm{c}$ & 19.0 & $4.83 a$ & $26.5 \mathrm{a}$ & $6.16 a$ & $18.2 \mathrm{a}$ & $4.72 \mathrm{a}$ \\
\hline PASC-975 & 8.7 & $1.62 \mathrm{c}$ & 16.8 & $4.53 \mathrm{a}$ & $24.8 \mathrm{a}$ & $4.91 \mathrm{~b}$ & $16.1 \mathrm{~b}$ & $3.29 \mathrm{~b}$ \\
\hline PASC-976 & 7.4 & $2.70 \mathrm{c}$ & 16.9 & $4.53 \mathrm{a}$ & $21.3 b$ & $5.22 b$ & $14.9 \mathrm{~b}$ & $2.52 \mathrm{c}$ \\
\hline PASC-977 & 5.3 & $1.80 \mathrm{c}$ & 16.5 & $2.24 \mathrm{~b}$ & $27.9 a$ & $3.52 \mathrm{~d}$ & $22.6 \mathrm{a}$ & $1.72 \mathrm{~d}$ \\
\hline PASC-978 & 5.8 & $3.96 a$ & 14.6 & $4.38 \mathrm{a}$ & $23.1 \mathrm{~b}$ & $5.36 \mathrm{~b}$ & $17.3 \mathrm{a}$ & $1.40 \mathrm{~d}$ \\
\hline PASC-979 & 8.7 & $4.40 \mathrm{a}$ & 18.6 & $5.19 a$ & $29.9 a$ & $6.26 a$ & $21.2 \mathrm{a}$ & $1.86 \mathrm{c}$ \\
\hline PASC-980 & 8.2 & $3.27 b$ & 17.2 & $3.76 \mathrm{a}$ & $24.0 \mathrm{~b}$ & $5.17 b$ & $15.8 \mathrm{~b}$ & $1.90 \mathrm{c}$ \\
\hline CV (\%) & 34.50 & 10.84 & 17.58 & 17.78 & 14.02 & 14.85 & 19.77 & 9.19 \\
\hline
\end{tabular}

Source: Authors (2020)

Where: Significant to 5\% probability of error by the Scott-Knott test; * Data transformed into the root of $x+1 .{ }^{* *}$ ns: no significant by $F$ test. 
This demonstrated that they had little variation among them. In groups II, III, IV, and V, it was grouped five, three, two, and two progenies, respectively. In group II, IV, and $\mathrm{V}$, the grouped progenies came from the same provenance, which may indicate a certain degree of kinship (Table 3).

Table 3 - Grouping resulting from the analysis of conglomeration by the Tocher method, using the 5 variables analyzed, based on the standard Euclidean mean distance, among 24 progenies of Araucaria angustifolia

\begin{tabular}{|c|c|c|c|c|c|c|c|c|}
\hline Groups & & & & Proge & enies & & & \\
\hline I & GUPR-952 & GUPR-958 & GUPR-964 & PASC-971 & PASC-977 & GUPR-960 & PASC-972 & GUPR-965 \\
\hline II & PASC-976 & PASC-980 & PASC-969 & PASC-975 & PASC-966 & & & \\
\hline III & GUPR-957 & PASC-973 & GUPR-959 & & & & & \\
\hline IV & PASC-970 & PASC-979 & & & & & & \\
\hline V & GUPR-951 & GUPR-963 & & & & & & \\
\hline VI & PASC-974 & & & & & & & \\
\hline VII & GUPR-956 & & & & & & & \\
\hline VIII & PASC-967 & & & & & & & \\
\hline IX & PASC-978 & & & & & & & \\
\hline
\end{tabular}

Source: Authors (2020)

The dendrogram of the similarity index of response based on the Mahalanobis nearest neighbor method allowed to observe the formation of two groups, one of which was formed by the progenies GUPR-951; GUPR-957; GUPR-959 and the second and largest with the others, as follows: GUPR-952; GUPR-956; GUPR-958; GUPR-960; GUPR-963; GUPR-964; GUPR-965; PASC-966; PASC-967; PASC-969, PASC-970; PASC971; PASC-972; PASC-973; PASC-974; PASC-975; PASC-976; PASC-977; PASC-978; PASC979; PASC-980 (Figure 2). The GUPR-951 and GUPR-952 progenies presented greater phenotypic divergence among the analyzed variables, even though both progenies were from the same provenance.

For the formation of the dendrogram by the nearest neighbor method based on Mahalanobis, it was considered the largest distance, 19.91 and 11.88 (obtained by D2) (Figure 2), formed by GUPR-951 and GUPR-952 progenies. In the present study, it is noticed a similarity among the progenies GUPR-952, GUPR-958, GUPR-964, PASC-971, 
PASC-977, GUPR-960, PASC-972 and GUPR-965, grouped by the Tocher method and of dissimilarity by the nearest neighbor, using the distance of Mahalanobis.

Figure 2 - Dendrogram of biometric dissimilarity among 24 progenies of Araucaria angustifolia, by the nearest neighbor grouping method, using the distance of Mahalanobis to the characteristics of growth in height and collar diameter at 30, 60 and 90 days, mean increase in height and collar diameter, emergency, emergency speed index and mean emergency time, from two provenances, Palmeira-SC (A) and Guarapuava-PR (B)

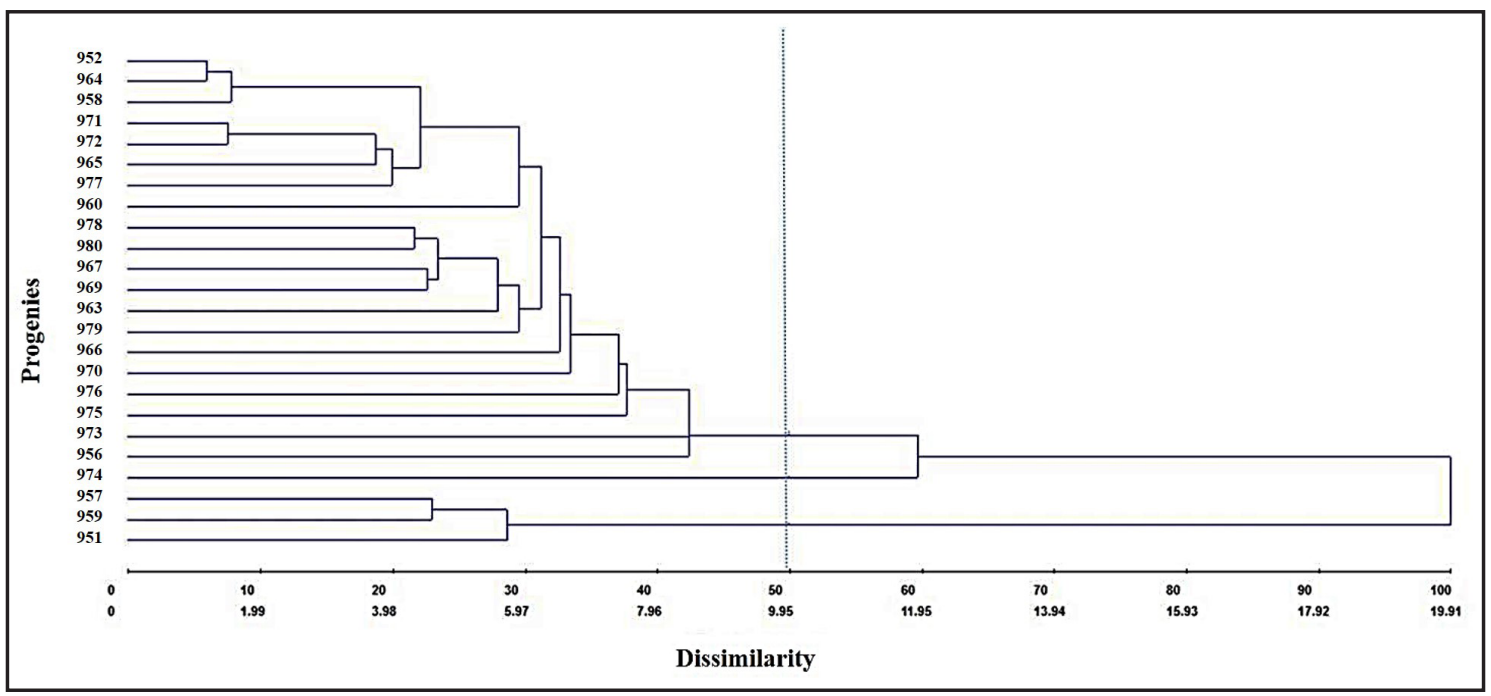

Source: Authors (2020)

Overall, clusters between progenies indicated little relation to the place of occurrence. The low diversity among populations from different locations may be due to their origin from a common ancestral population, or that these populations may have undergone anthropic action, fruit dispersal via animals, and cross-pollination. Carpentieri-Pípolo et al. (2000) recommended the use of parental genotypes with the greatest divergence possible to maximize heterosis, increase the probability of occurrence of advanced upper segregants, and broaden the genetic basis. In a genetic breeding program, measurements of genetic divergence obtained before the realization of any crossbreeding can help breeders concentrate their efforts on the most promising combinations, which recommend using phenotypic data and 
molecular markers for greater results' reliability (CARPENTIERI-PÍPOLO et al., 2000).

The variable index of emergency speed presented a relatively high positive correlation index when related to the emergency $(P<0.05)$ (Table 4). This affirmation is explained by the high rate of emergence in a short time, influenced by the species morphology since the seeds are recalcitrant and they have a large reserve capacity for their initial growth and establishment as seedlings in the initial stage of development.

Table 4 - Coefficients of simple correlation of Pearson estimated between the tests of physical characteristics of the seeds and seedlings of different provenances and progenies of Araucaria angustifolia

\begin{tabular}{|c|c|c|c|c|c|c|c|c|c|c|c|}
\hline & h30 & $\operatorname{cd} 30$ & h60 & cd60 & h90 & cd90 & Inc.h & Inc.cd & E & ISE & MTE \\
\hline h30 & 1.00 & $-0.13^{\mathrm{ns}}$ & $0.48^{* *}$ & $0.25^{* *}$ & $0.18^{*}$ & $0.17^{\mathrm{ns}}$ & $-0.42^{* *}$ & $0.19 *$ & $0.15^{\text {ns }}$ & $0.10^{\mathrm{ns}}$ & $-0.03^{\text {ns }}$ \\
\hline $\operatorname{cd} 30$ & & 1.00 & $0.20 *$ & $0.59 * *$ & $0.21 *$ & $0.58^{* *}$ & $0.20 *$ & $-0.64^{* *}$ & $-0.44^{* *}$ & $-0.46^{* *}$ & $0.41 * *$ \\
\hline h60 & & & 1.00 & $0.28 * *$ & $0.60 * \star$ & $0.30 * *$ & $0.26^{\star \star}$ & $0.08^{\mathrm{ns}}$ & $-0.01^{\mathrm{ns}}$ & $-0.01^{\mathrm{ns}}$ & $-0.36^{\text {ns }}$ \\
\hline cd60 & & & & 1.00 & $0.12^{\mathrm{ns}}$ & $0.85^{* *}$ & $-0.03^{\mathrm{ns}}$ & $0.05^{\mathrm{ns}}$ & $-0.19 *$ & $-0.33^{* *}$ & $0.45^{* *}$ \\
\hline h90 & & & & & 1.00 & $0.16^{\mathrm{ns}}$ & $0.82^{* *}$ & $-0.06^{\mathrm{ns}}$ & $-0.12^{\mathrm{ns}}$ & $-0.08^{\mathrm{ns}}$ & $-0.04^{\text {ns }}$ \\
\hline $\operatorname{cd} 90$ & & & & & & 1.00 & $0.06^{\text {ns }}$ & $0.23 *$ & $-0.19 *$ & $-0.30 * *$ & $0.42^{* *}$ \\
\hline Inc.h & & & & & & & 1.00 & $-0.16^{\mathrm{ns}}$ & $-0.20 *$ & $-0.15^{\mathrm{ns}}$ & -0.01 ns \\
\hline Inc.cd & & & & & & & & 1.00 & $0.37^{* *}$ & $0.31 * *$ & $-0.13^{\text {ns }}$ \\
\hline$E$ & & & & & & & & & 1.00 & $0.91 * *$ & $-0.43 * *$ \\
\hline ISE & & & & & & & & & & 1.00 & $-0.74 * *$ \\
\hline MTE & & & & & & & & & & & 1.00 \\
\hline
\end{tabular}

Source: Authors (2020)

Where: $\mathrm{h} 30$ = height at 30 days after sowing; $\mathrm{cd} 30$ = collar diameter at 30 days after sowing; $\mathrm{h} 60=$ height at 60 days after sowing; cd60 = collar diameter at 60 days after sowing; h90 = height at 90 days after sowing; $\operatorname{cd} 90$ = collar diameter at 90 days after sowing; Inc.h = mean increase in height after 90 days; $=$ Inc.cd = mean increase in collar diameter after 90 days; $\mathrm{E}=$ emergency; ISE: index speed emergency; MTE $=$ mean time of emergency. ${ }^{*}=r$ significant at $5 \%$ probability by the $t$ test; ${ }^{*}=r$ significant at $1 \%$ probability by t-test; $n s=r$ not significant.

The variable collar diameter was the one that, for most of the relationships, presented low correlation coefficient estimates, even though they were significant. Thus, it is risky to use this variable as an indicator to select the best superior genetic material in a certain breeding program.

As a criterion to select the superior genetic material of $A$. angustifolia, the selection of $20 \%$ of the evaluated progenies that presented the highest frequency of superiority 
(SOUZA; AGUIAR, 2012) was adopted in the characteristics such as pine cone diameter, pine cone weight, number of full pine nuts, number of failures and seeds, the weight of full pine nuts, emergency, emergency speed index, mean emergency time, mean increase in height and the average increase in collar diameter. Based on the selection criteria, the following genetic materials were selected: PASC-971, PASC-975, PASC-970, PASC-975, and PASC-980.

In summary, the results indicated that the progenies selected by the selection criteria presented a certain standard behavior among the evaluated variables. However, there is also substantial genetic variability, good genetic control in the characters to be explored by selecting the best provenances and progenies for the characters studied, which can enhance the seed orchard.

Sebbenn and Ettori (2001), when finding significant genetic differences of the characters analyzed, considered in their works that the genetic material is suitable for the ex situ genetic conservation of the population. It is necessary to highlight that the evaluation of this work was in the initial stage, and only though monitoring the development of the superior genetic material of $A$. angustifolia on the field can confirm these results. If such a pattern of genetic variation persists over the years to adulthood, it can be considered that the genetic material sampled shows good genetic variability and is suitable for use in genetic improvement and forest restoration programs.

\section{CONCLUSIONS}

There is genetic variability among the provenances and progenies for most of the quantitative traits studied for Araucaria angustifolia and, therefore, the possibility of obtaining gains by selection among and within provenances.

The selection among and within the provenances suggests the possibility of capitalizing large genetic gains, especially for characters of weight and diameter of the pine cone, weight, and number of pine nuts per pine cone and tree growth.

The initial growth behavior of Araucaria angustifolia evaluated in the field and in the nursery stage presented high genetic control and could be used to evaluate the genetic variability of samples of the species populations. 


\section{REFERENCES}

ALVARES, C. A.; SENTELHAS, P. C.; STAPE, J. L. Modeling monthly meteorological and agronomic frost days, based on minimum air temperature, in Center-Southern Brazil. Theoretical and Applied Climatology, Wien, v. 134, 177-191, 2018.

ANSELMINI, J. I. Fenologia reprodutiva da Araucaria angustifolia(Bert.) O. Ktze. na região de Curitiba, PR.2005. Dissertação (Mestrado em Agronomia) - Universidade Federal do Paraná, Curitiba, 2005.

ANSELMINI, J. I.; ZANETTE, F.; BONA, C. Fenologia reprodutiva da Araucaria angustifolia (Bert.) O. Ktze, na região de Curitiba - PR. Floresta e Ambiente, Rio de Janeiro, v. 13, n. 1, p. 44-52, 2006.

CARPENTIERI-PÍPOLO, V. et al. Seleção de genótipos parentais de acerola com base na divergência genética multivariada. Pesquisa Agropecuária Brasileira, Brasília, v. 35, p. 16131619, 2000.

CARVALHO, N. M.; NAKAGAWA, J. Sementes: ciência, tecnologia e produção. 5. ed. Jaboticabal: FUNEP, 2012. 590 p.

CRUZ, C. D. Programa GENES: Estatística experimental e matrizes. Viçosa, MG: Editora UFV, 2006. 285 p.

FIGUEIREDO FILHO, A. et al. Produção de sementes de Araucaria angustifolia em plantio e em floresta natural no centro-sul do estado do Paraná. Floresta, Curitiba, v. 41, n. 1, p. 155-162, 2011.

GUEDES, R. S. et al. Teste de comprimento de plântula na avaliação da qualidade fisiológica de sementes de Amburana cearensis (Allemão) A. C. Smith. Semina: Ciências Agrárias, Londrina, v. 36, n. 4, p. 2373-2382, 2015.

KRUPEK, R. A.; RIBEIRO, V. Biometria e Germinação de Sementes de Araucaria angustifolia (Bert.) O. Kuntze provenientes de um remanescente florestal do Município de Turvo (PR). Revista Ciências Exatas e Naturais, Guarapuava, v. 12, n. 1, 2010.

MAGUIRE, J. D. Speeds of germination-aid selection and evaluation for seedling emergence and vigor. Crop Science, Madison, v. 2, p. 176-177, 1962.

MANTOVANI, A.; MORELLATO, P. C.; REIS, M. S. Fenologia reprodutiva e produção de sementes em Araucaria angustifolia (Bert.) O. Kuntze. Brazilian Journal of Botany, São Paulo, v. 27, n. 4, p. 787-796, 2004.

MARCOS FILHO, J. M. Fisiologia de sementes de plantas cultivadas. Piracicaba: FEALQ, 2005. $495 \mathrm{p}$.

MATTOS, J. R. D. O pinheiro Brasileiro. Florianópolis: UFSC, 2011. 700 p.

MOREIRA-SOUZA, M.; CARDOSO, E. J. B. N. Practical method for germination of Araucaria angustifolia seeds. Scientia Agrícola, Piracicaba, v. 60, n. 2, 2003. 
OLIVEIRA, A. C. S. et al. Testes de vigor em sementes baseados no desempenho de plântulas. Inter Science Place, São Camilo, n. 4, p. 1-21, 2009.

PALADINI, M. V. Caracterização de frutos, divergência genética e estrutura espacial de jaboticabeiras nativas de fragmento florestal em Clevelândia-PR. 2016. Tese (Doutorado em Agronomia) - Universidade Tecnológica Federal do Paraná, Pato Branco, 2016.

PIRES, V. C. Caracterização biométrica de pinhas e sementes de Araucaria angustifolia. 2016. Dissertação (Mestrado em Ciência Florestal) - Faculdade de Ciências Agronômicas, Universidade Estadual Paulista, Botucatu, 2016.

R STUDIO TEAM. RStudio: Integrated Development for R. Boston: R Studio, 2015.

SANTOS, F. S. et al. Biometria e qualidade fisiológica de sementes de diferentes matrizes de Tabebuia chrysotricha. Scientia Forestalis, Piracicaba, v. 37, n. 82, p. 163-173, 2009.

SCHUCH, L. O. B.; NEDEL, J. L.; ASSIS, F. N. Crescimento em laboratório de plântulas de aveiapreta (Avena strigosa Schreb.) em função do vigor das sementes. Revista Brasileira de Sementes, Brasília, v. 21, n. 1, p. 229-234, 1999.

SEBBENN, A. M.; ETTORI, L. C. Conservação genética ex situ de Esenbeckia leiocarpa, Myracrodruon urundeuva e Peltrophorum dubium em teste de progênies misto. Revista do Instituto Florestal, São Paulo, v. 13, n. 2, p. 201-211, 2001.

SILVA, C. V. Aspectos da obtenção e comercialização de pinhão na região de Caçador, SC. 2006. Dissertação (Mestrado em Recursos Genéticos Vegetais) - Universidade Federal de Santa Catarina, Florianópolis, 2006.

SOLÓRZANO-FILHO, J. A. Demografia e ecologia da dispersão de sementes de Araucaria angustifolia (Bert.) Kutze (Araucariaceae), numa população relictual em Campos doJordão, SP.2001. Dissertação (Mestrado em Ciências) -Departamento de Ecologia, Universidade de São Paulo, São Paulo, 2001.

SOUZA, M. A. M. Metodologias não destrutivas para avaliação das tensões de crescimento em Eucalyptus dunnii Maiden. 2006. Tese (Doutorado em Engenharia Florestal) - Universidade Federal do Paraná, Curitiba, 2006.

SOUZA, V. A.; AGUIAR, A. V. Programa de melhoramento genético de Araucária da Embrapa Florestas: situação atual e perspectivas. Colombo: EMBRAPA Florestas, 2012.

SOUZA, V. A.; HATTEMER, H. H. Fenologia reprodutiva de Araucaria angustifolia no Brasil. Boletim Pesquisa Florestal, Colombo, n. 47, p. 19-32, 2003.

VERNALHA, M. M. et al. Considerações sobre a semente da Araucaria angustifólia. Acta Biológica Paranaense, Curitiba, v. 1, n. 3-4, p. 39-96, 1972.

WENDLING, I.; DELGADO, M. E. Produção de mudas de araucária em tubetes. Colombo: EMBRAPA Florestas, 2008. 8 p.

WREGE, M. S. et al. Predicting Current and Future Geographical Distribution of Araucaria in Brazil for Fundamental Niche Modeling. Environment and Ecology Research, [s. 1.], v. 4, n. 5, p. 269-279, 2016.

ZANETTE, F. Enxertia de araucária para produção de pinhão. Curitiba: Sistema FAEP, 2014. $16 \mathrm{p}$. 


\section{Authorship Contribution}

\section{1 - Dionatan Gerber}

Forestry Engineer, MSc.

https://orcid.org/0000-0002-0544-1679•dionatan_gerber@hotmail.com

Contribution: Conceptualization, Investigation, Methodology, Supervision, Visualization, Writing - original draft

\section{2 - Eleandro José Brun}

Forestry Engineer, Dr., Professor

https://orcid.org/0000-0003-3832-1320•eleandrobrun@utfpr.edu.br

Contribution: Conceptualization, Funding acquisition, Project administration, Resources, Writing - review \& editing

\section{3 - Larissa Regina Topanotti}

Forestry Engineer, MSc.

https://orcid.org/0000-0001-5066-4196•larissa.topanotti@ufsc.br

Contribution: Investigation, Visualization, Writing - original draft

\section{4 - Josângela de Jesus Ferreira}

Forestry Engineer

https://orcid.org/0000-0001-9428-2544•jo_ferreira16@yahoo.com.br Contribution: Investigation, Writing - review \& editing

\section{5 - Douglas Anry Porrua}

Forestry Engineer, MSc.

https://orcid.org/0000-0002-6196-1273•douglas_porrua@hotmail.com

Contribution: Investigation, Writing - review \& editing

\section{6 - Mauricio Romero Gorenstein}

Forestry Engineer, Dr., Professor

https://orcid.org/000-0003-3181-1669•mauriciorg@utfpr.edu.br

Contribution: Formal Analysis 


\section{7 - Américo Wagner Júnior}

Agronomist, Dr., Professor

https://orcid.org/0000-0001-5081-5281•americowagner@utfpr.edu.br

Contribution: Conceptualization, Formal Analysis, Methodology, Project administration, Resources, Supervision, Writing - review \& editing

\section{How to quote this article}

Gerber, D.; Brun, E. J.; Topanotti, L. R.; Ferreira, J. J.; Porrua, D. A.; Gorenstein, M. R.; Wagner Junior, A. Genetic variability of Araucaria angustifolia Bertol. initial growth: subsidy to the formation of seed orchards. Ciência Florestal, Santa Maria, v. 31, n. 1, p. 310-332, 2021. DOI 10.5902/1980509841712. Available from: https://doi.org/10.5902/1980509841712. Accessed: xx abbreviated month 202x. 